\title{
Effects of urogastrone-epidermal growth factor on intestinal brush border enzymes and mitotic activity
}

\author{
R A Goodlad, K B Raja, T J Peters, N A Wright
}

\begin{abstract}
The wet weight of the stomach, small intestine, caecum, and colon were significantly reduced $(p<0.001)$ in intravenously fed rats compared with orally fed controls. Human epidermal growth factor (urogastrone) reversed this atrophy. Detailed analysis of the small intestine showed a similar effect on intestinal crypt cell population, mitoses per crypt, and protein content. Brush border $\gamma$ glutamyltransferase and $\alpha$ glucosidase activities were reduced by up to $50 \%$ throughout the small intestine of the animals fed intravenously. The specific activities (mU/mg protein) were unchanged, as a concomitant decrease in the tissue weight and protein content also occurred. Intestinal brush border enzyme activities in the rats treated with urogastrone-epidermal growth factor were restored to those seen in the orally fed rats except for $\alpha$ glucosidase activity in the proximal gut. In addition, the specific activity of $\gamma$ glutamyltransferase was highly significantly increased $(p<0.01)$ in all regions of the small intestine. Thus, although urogastrone administration prevents the decrease in brush border enzyme activity seen after the removal of luminal nutrition, the response seems to differ depending on the intestinal location, with the specific activities of some enzymes being higher than those seen in orally fed rats. Urogastrone-epidermal growth factor can thus significantly increase the functional ability of the intestine in addition to its trophic effects.
\end{abstract}

While many aspects of the molecular biology of epidermal growth factor are now well understood, ' its role in vivo is still uncertain. It stimulates the proliferation and maturation of the neonatal intestine, ${ }^{2-}$ the functional maturity of the preweaning intestine, ${ }^{5}$ and the maturation of brush border enzymes in the neonate. ${ }^{67}$ Recent studies have also shown human epidermal growth factor, or urogastrone, to be a potent stimulator of intestinal epithelial cell proliferation in adult animals ${ }^{89}$ and in humans. ${ }^{10}$ This proliferative effect is dependent on the induction of polyamine synthesis." The effect of epidermal growth factor on intestinal function, however, remains unclear. The aim of this study was to (i) investigate the effects of urogastrone-epidermal growth factor on the activity of two intestinal brush border enzymes in adult rats and (ii) to determine whether the changes in enzyme activities were related to variations in proliferative activity.

\section{Methods}

EXPERIMENTAL PLAN

Three groups of 12 rats (male, 230-240 $\mathrm{g}$ Wistar strain) (Olac, Blackthorn, Oxon) were used. The first group was fed on a standard pelleted diet (Labshure PRD), the second on an intravenous diet which was intended to be isocaloric, ${ }^{89}$ and the third was given the intravenous diet and urogastrone-epidermal growth factor $(60 \mu \mathrm{g} / \mathrm{rat} /$ day). The rats were maintained on the appropriate diet for eight days. The urogastrone was recombinant urogastrone and had the same amino acid sequence and biological activity as natural epidermal growth factor. ${ }^{12}$

\section{INTRAVENOUS NUTRITION}

Rats were anaesthetised with intramuscular fentanyl and fluanisone and intraperitoneal diazepam and the right external jugular vein cannulated with silastic cannula. The tubing was tunneled subcutaneously to the back of the neck and connected via a stainless steel skin button and tether to a fluid swivel joint (Scientific Marketing Associates, London) and thence by vinyl tubing to a multichannel peristaltic pump (Watson Marlow, Falmouth, Cornwall). The intravenous diet was stored at $4^{\circ} \mathrm{C}$ and infused into the rats at $60 \mathrm{ml} / \mathrm{rat} /$ day, giving $1.8 \mathrm{~g}$ nitrogen, $6.9 \mathrm{~g}$ lipid, $8.5 \mathrm{~g}$ glucose, and $1047 \mathrm{~kJ}$ per kg per day. ${ }^{9}$

\section{NECROPSY PROCEDURE}

The animals were anaesthetised with pentobarbitone and killed by exsanguination. The entire gastrointestinal tract was removed, rinsed with ice cold $0.15 \mathrm{~mol} / 1 \mathrm{NaCl}$, blotted, and weighed. Two centimetre lengths of small intestine were cut from sites 10,50 , and $90 \%$ from the proximal end of the small intestine. The segments of intestine were weighed, placed in $2 \mathrm{ml}$ of ice cold $20 \mathrm{mmol} / \mathrm{l}$ hydroxyethylpiperazine ethanesulphonic acid $0 \cdot 15 \mathrm{~mol} / 1 \mathrm{NaCl}$

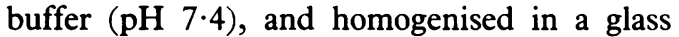
Dounce Homogeniser (Kontes Glass, Vineland, NJ, USA). The homogenate was stored frozen at $-20^{\circ} \mathrm{C}$ until analysis.

BIOCHEMICAL ASSAYS

$\alpha$ Glucosidase (EC 3.2.1.20) and $\gamma$ glutamyltransferase (EC 2.3.2.2) activities were measured fluorimetrically by the methods of Peters $^{13}$ and Smith et al, ${ }^{1+}$ respectively. An aliquot of intestinal homogenate of suitable 
Organ weights in orally fed, intravenously fed (TPN), and TPN plus urogastrone-epidermal growth factor (URO-EGF) treated rats (mean (SEM))

\begin{tabular}{lccc}
\hline & $\begin{array}{l}\text { Orally fed } \\
(n=12)\end{array}$ & $\begin{array}{l}T P N \\
(n=12)\end{array}$ & $\begin{array}{l}T P N+\text { URO-EGF } \\
(n=12)\end{array}$ \\
\hline Initial weight (g) & $230(3)$ & $239(3)$ & $241(4)$ \\
Final weight (g) & $289(4)$ & $224(3)^{\star}$ & $219(4)$ \\
Stomach weight (g) & $1 \cdot 73(0 \cdot 04)$ & $1 \cdot 15(0 \cdot 03)^{\star}$ & $1 \cdot 63(0 \cdot 03) \dagger$ \\
Small intestine weight (g) & $10 \cdot 5(0 \cdot 3)$ & $4 \cdot 9(0 \cdot 1)^{\star}$ & $7 \cdot 7(0 \cdot 2) \dagger$ \\
Caecum weight (g) & $1 \cdot 37(0 \cdot 06)$ & $0 \cdot 86(0 \cdot 36)^{\star}$ & $1 \cdot 37(0 \cdot 07) \dagger$ \\
Colon weight (g) & $1 \cdot 88(0 \cdot 06)$ & $0 \cdot 91(0 \cdot 03)^{\star}$ & $2 \cdot 02(0 \cdot 08) \dagger$ \\
Small intestine length (cm) & $123(2)$ & $110(1)^{\star}$ & $111(1)$ \\
Colon length (cm) & $20 \cdot 0(0 \cdot 3)$ & $13 \cdot 2(0 \cdot 2)$ & $15 \cdot 3(0 \cdot 4) \dagger$ \\
\hline
\end{tabular}

*Significantly lower than the orally fed group $(\mathrm{p}<0.001)$;

†Significantly greater than the TPN group $\mathrm{p}<0.001)$

dilution was mixed with buffered substrate (4methylumbelliferyl $\alpha$-D-glucopyranoside and $\gamma$-glutamyl-7-amino-4-methyl-coumarin plus glycyl-glycine, as appropriate) and incubated at $37^{\circ} \mathrm{C}$ for up to 30 minutes. The reaction was stopped by the addition of glycine buffer and the fluorescent product assayed with a Perkin-Elmer (Beaconsfield, Bucks) LS3 fluorimeter. Fluorescence was converted to nanomoles of product formed by reference to a standard block, previously calibrated with the fluorescent product. Protein was determined by the method of Bradford, ${ }^{15}$ with bovine serum albumin as standard.

\section{HISTOLOGY}

Mucosa from the middle of the small intestine was embedded in wax, orientated perpendicular to the surface, and alternate $4 \mu \mathrm{m}$ sections cut and stained with haematoxylin and eosin. Slides

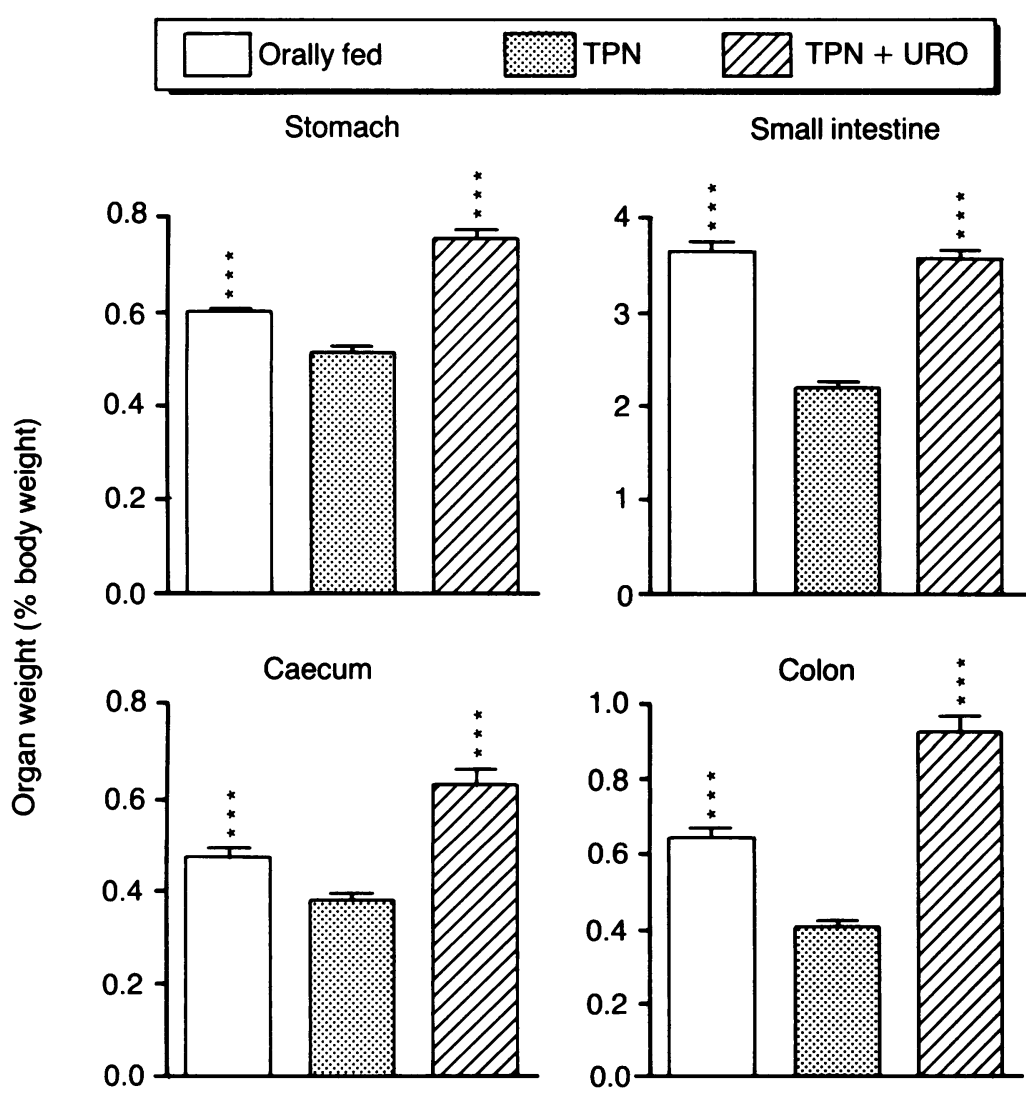

Figure I: Effects of oral feeding, intravenous nutrition (TPN), and TPN + urogastroneepidermal growth factor (URO) on the relative weight of the rat stomach, small intestine, caecum, and colon. Values expressed as per cent total body weight. $\star \star \star S i g n i f i c a n t l y ~ g r e a t e r$ than the TPN group, $p<0.001$. were examined systematically until well orientated crypts (sectioned along the axis of the crypt lumen) were found. The crypt to the crypt-villus junction was scored, recording the presence and location of mitotic cells and crypt length. The selection of well orientated, axially sectioned crypts leads to the overestimation of mitotic indices, on account of the mitotic figures migrating towards the centre of the crypt. This was corrected for by Tannock's method. ${ }^{16}$ The product of the crypt length and the crypt diameter (circumferential cell count) gave the crypt cell population. ${ }^{17}$ Five animals per group and 30 crypts per animal were scored. All slides were scored blind - that is, the person reading the slides was unaware of the group to which the slides belonged.

\section{STATISTICS}

All results are presented as the mean (SEM). Data were tested by a two-sided $t$ test.

\section{Results}

The orally fed rats gained weight, while the rats fed intravenously lost weight (Table). The wet weight of the stomach, small intestine, caecum, and colon were significantly reduced $(p<0.001)$ after intravenous feeding. The reduction in intestinal weight as well as in stomach, caecum, and colon weight was, however, prevented by concomitant urogastrone-epidermal growth factor administration. Due to the apparent differences in body weight between the three groups, the relative weights of the stomach, caecum, and colon (expressed as a per cent of body weight) were significantly $(p<0.001)$ heavier in the group receiving a combination of intravenous feeding and urogastrone than the orally fed group (Fig 1). The length of the small intestine was decreased in the group fed intravenously and was little changed by urogastrone treatment. The colon was appreciably shorter after intravenous feeding but was significantly lengthened after urogastrone administration.

The crypt length (cell column count) was reduced $(p<0.001)$ in the rats fed intravenously (Fig 2) and was restored to normal levels when urogastrone was administered. Intravenous feeding of the animals also resulted in over a $30 \%$ reduction in the crypt diameter, this being partially restored with urogastrone treatment (Fig 2). Consequentially, the crypt cell population in the third group, although significantly greater than in the group fed intravenously $(p<0.001)$ was less than that seen in the orally fed rats $(p<0.01)$. No significant changes in Tannock's factor were observed in the experimental groups (mean (SEM) orally fed 0.447 $(0.031)$, intravenous $0.479(0.006)$, intravenous + urogastrone $0.466(0.014))$. The mitotic index was reduced to a small extent by parenteral nutrition, but as the denominator for this index had also decreased the number of mitoses per crypt column and per crypt was significantly decreased $(p<0.01)$. All measures of mitotic activity were increased to normal levels by urogastrone treatment (Fig 2).

A similar pattern was also seen in the weight of 

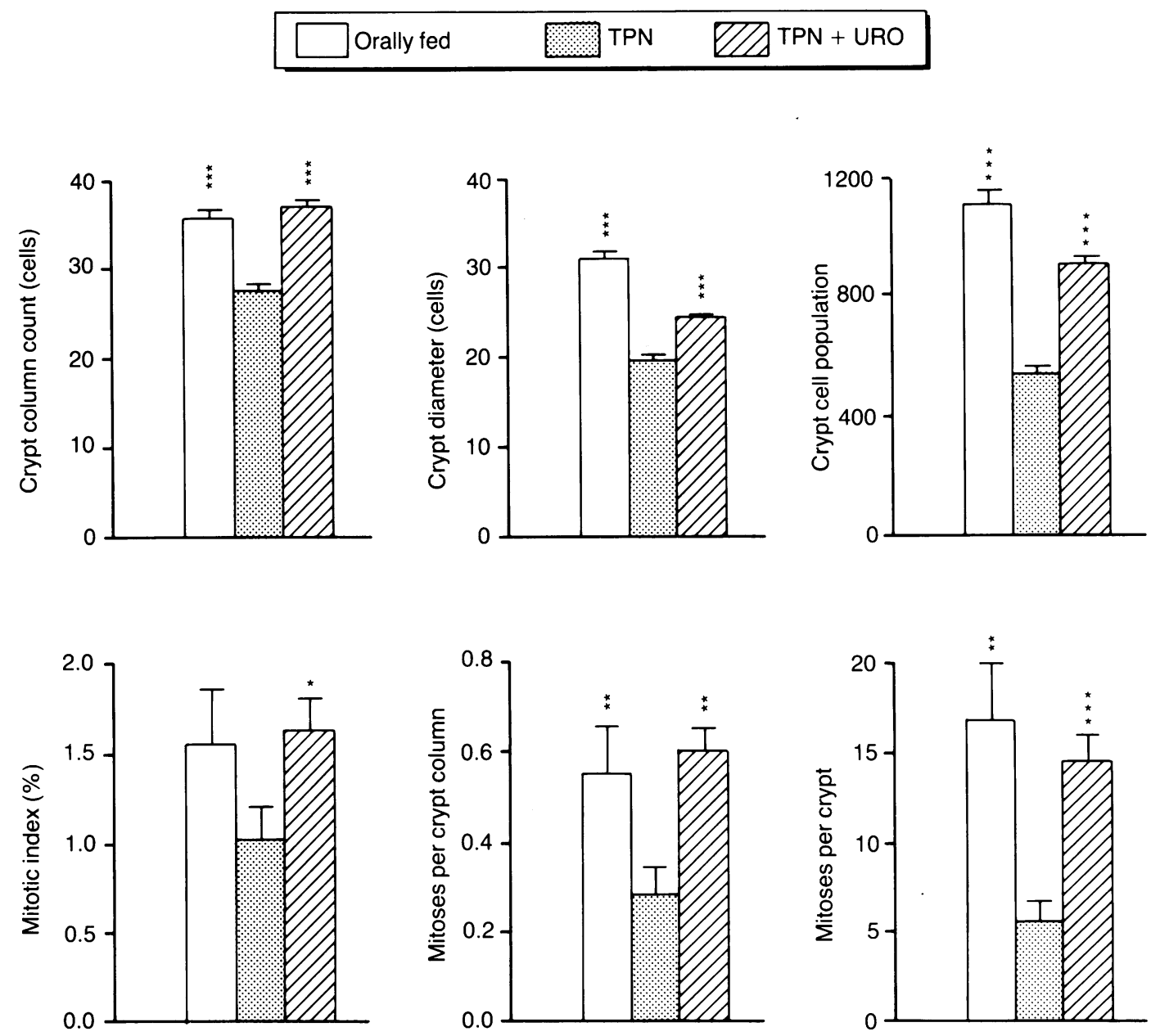

Figure 2: Effects of oral feeding, intravenous nutrition $(T P N)$, and TPN + urogastrone-epidermal growth factor $(U R O)$ on crypt cell column count, crypt diameter, estimated crypt cell population, mitotic index, number of mitotic cells per crypt column, and on the estimated number of mitoses per crypt in the mid-small intestine. Significantly greater than the TPN group: ${ }^{\star} p<0.05$, $\star \star p<0 \cdot 01, \star \star \star p<0 \cdot 001$.

the isolated intestinal segments (Fig 3). The protein content of the tissue samples obtained from the three regions of the gut was also significantly reduced in the group fed intravenously. The values were likewise significantly increased by the urogastrone administration, though not to the same extent as with the weights (compare Fig 3 top and bottom).

Brush border $\alpha$ glucosidase and $\gamma$ glutamyltransferase activities (mU/cm gut) were reduced by $25-50 \%$ in all regions of the small intestine of the intravenously fed animals compared with the orally fed group (Figs 4 and 5, top). Enzyme activity was restored to the levels seen in orally fed animals after urogastrone administration, with the exception of $\alpha$ glucosidase in the proximal intestine. When enzyme activities were expressed as specific activity (mU/ $\mathrm{mg}$ protein), no significant changes were seen in any of the three intestinal regions of the group fed intravenously compared with oral values (Figs 4 and 5, bottom). This observation is attributable to the fact that the intestinal protein content decreased by a similar amount in all three intestinal regions during intravenous feeding (Fig 3, bottom). Furthermore, $\alpha$ glucosidase specific activities were not significantly altered after concomitant urogastrone administration. In contrast, the specific activity of $\gamma$ gluta- myltransferase was increased in all regions after urogastrone administration compared with values in either the intravenously or the orally fed groups (Fig 4, bottom).

\section{Discussion}

The proliferative effects of urogastroneepidermal growth factor were confirmed in the present experiment, especially when the weight increase of the orally fed group was taken into account. Although the proliferative response was evident in the small intestine, it was generally less pronounced than that in other regions of the gastrointestinal tract. This may be due to differences in the susceptibility of the organs to the effects of urogastrone. There has also been recent evidence of the colon having considerably more epidermal growth factor receptors than the small intestine. ${ }^{18}$ Data for the caecum and stomach are not available.

Morphometric analysis of the small intestinal mucosa showed that the crypt length was significantly reduced by intravenous feeding and restored by urogastrone treatment. The crypt cell population values, however, seemed not to be fully restored in the group receiving intravenous feeding + urogastrone due to the incomplete recovery of the crypt diameter. The crypt 
Figure 3: Effects of oral feeding, intravenous nutrition $(T P N)$, and TPN + urogastrone-epidermal growth factor (URO) on the weight and protein content of small intestine. The sites in the intestine were defined by their percentage length from the proximal end. Values expressed per unit length. Significantly greater than the TPN group: ${ }^{\star} p<0.05$, $\star \star p<0.01, \star \star \star p<0.001$.

\begin{tabular}{lll}
$\square$ Orally fed $\quad \square$ TPN & QDT TPN + URO \\
\hline
\end{tabular}
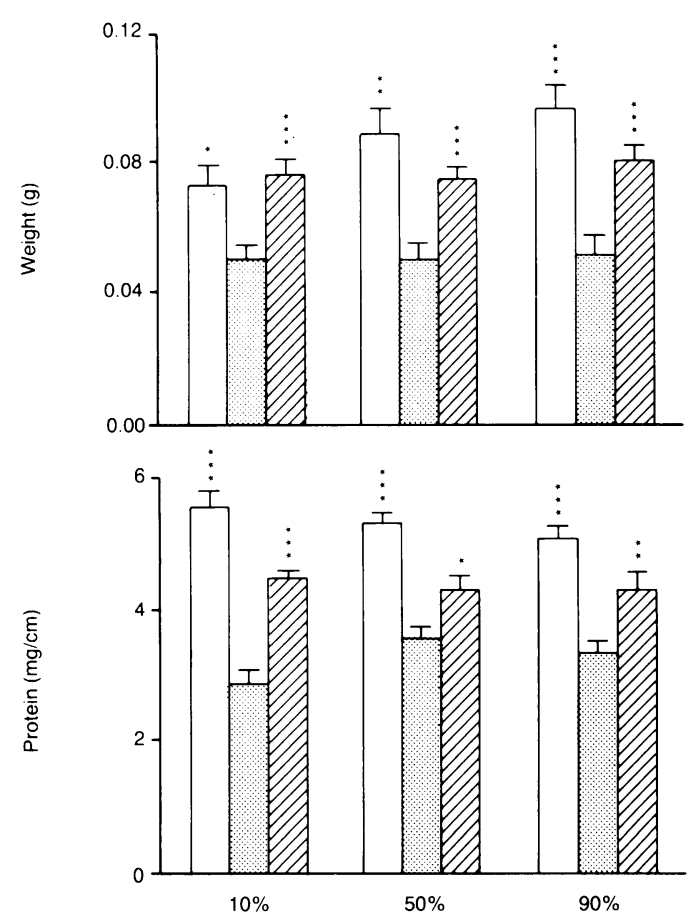

cell population data showed remarkable similarities to the small intestinal weight and protein data. The changing crypt cell population would explain the lack of a noticeable decrease in mitotic index, and again shows the importance of choosing the correct denominator. A similar lack of proliferative activity was first seen in our studies on the actions of prostaglandins on the

\begin{tabular}{|c|c|c|}
\hline Orally fed & TPN & VDT TPN + URO \\
\hline
\end{tabular}
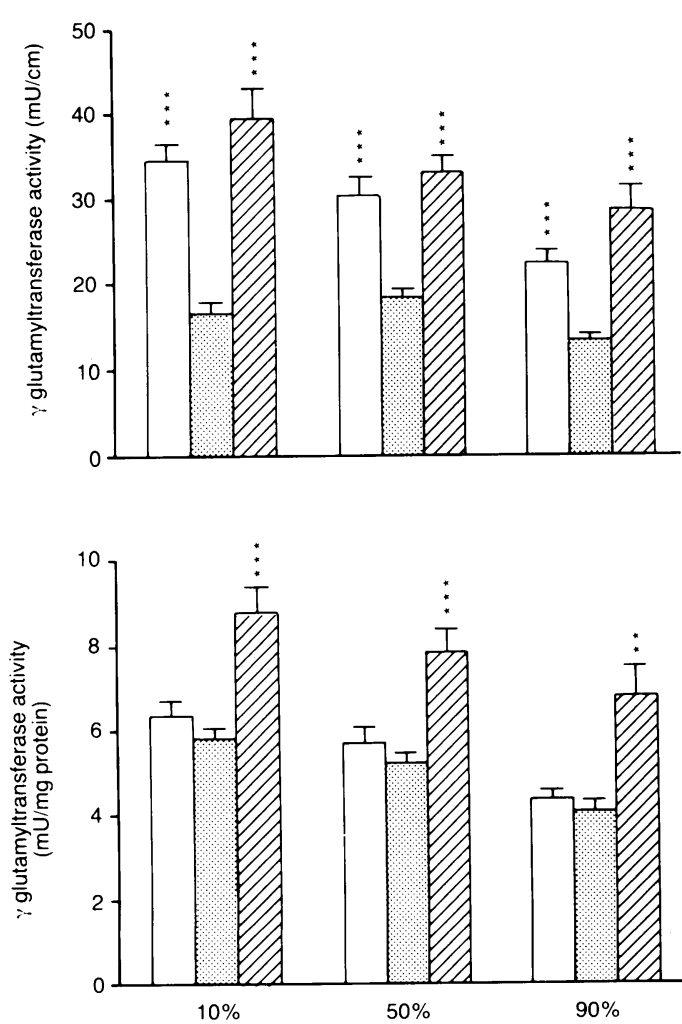

stomach, but as the length of the gastric glands were also increased, the proliferative activity and gland cell production were in fact appreciably increased. ${ }^{19}$

The activities of both $\alpha$ glucosidase and $\gamma$ glutamyltransferase fell greatly with intravenous feeding. The absence of a change in the specific activity with such feeding suggests that the decrease in enzyme activity is a consequence of intestinal atrophy. The activity of both enzymes was restored to normal after urogastrone treatment, with the exception of the proximal intestinal $\alpha$ glucosidase. The lack of response in the proximal region indicates that 'luminal nutrition' may be particularly important for the maturation of $\alpha$ glucosidase. Discrepancies in the enzyme activities were, none the less, more evident when values were expressed as $\mathrm{mU} / \mathrm{mg}$ protein: $\gamma$ glutamyltransferase showed a significant increase in all regions after urogastrone administration, while $\alpha$ glucosidase specific activities were moderately decreased or unchanged compared with values in the group fed intravenously. These differences may be a function of the intestinal localisation of the enzymes: $\alpha$ glucosidase activity is relatively constant along the villus while $\gamma$ glutamyltransferase shows a pronounced gradation in activity along the villus, with peak activity at the tip..$^{20}$ The increased specific activity could thus be the consequence of either decreased cell loss at the villus tip or a downward migration of the functional zone of the villus. The magnitude of the increase in mitoses per crypt was greater than that of the cell population, suggesting that the influx of cells into the villus was indeed greater. Alteration in villus function, which can be attributed to the influx of cells from the crypt, even at the expense of maintaining the crypt cell population, has been observed in models of starvation and refeeding. ${ }^{21}$

Several studies have now shown that epidermal growth factor can stimulate proliferation and maturation of the neonatal rodent intestine $^{5-7}$ and fetal human jejunum. ${ }^{22}$ The hormone may act either luminally or systemically, as it can pass through the intestine of suckling and weanling rats. ${ }^{23}$ Data on the adult are scarce, but it has recently been reported that both systemic and luminal epidermal growth factor infusion can stimulate galactose and glycine absorption from Thiry-Vella loops, ${ }^{2+}$ and the administration of physiological doses to mature mice can enhance mucosal iron absorption. ${ }^{25}$

While the specific enzyme activity is a useful measure of intestinal maturity and function, the activity available per unit gut length is the most relevant physiologically with respect to nutrient absorption, and as no difference in gut length was noted between the groups fed intravenously and intravenously + urogastrone, it can be concluded that as well as increasing mucosal mass, urogastrone-epidermal growth factor appreciably increased the ability of the adult small intestine to perform its digestive functions.

We thank Dr H Gregory of ICI Pharmaceuticals, Alderley Park, Macclesfield, for the gift of the urogastrone and acknowledge the technical assistance of $\mathrm{Mr}$ W Lenton. 

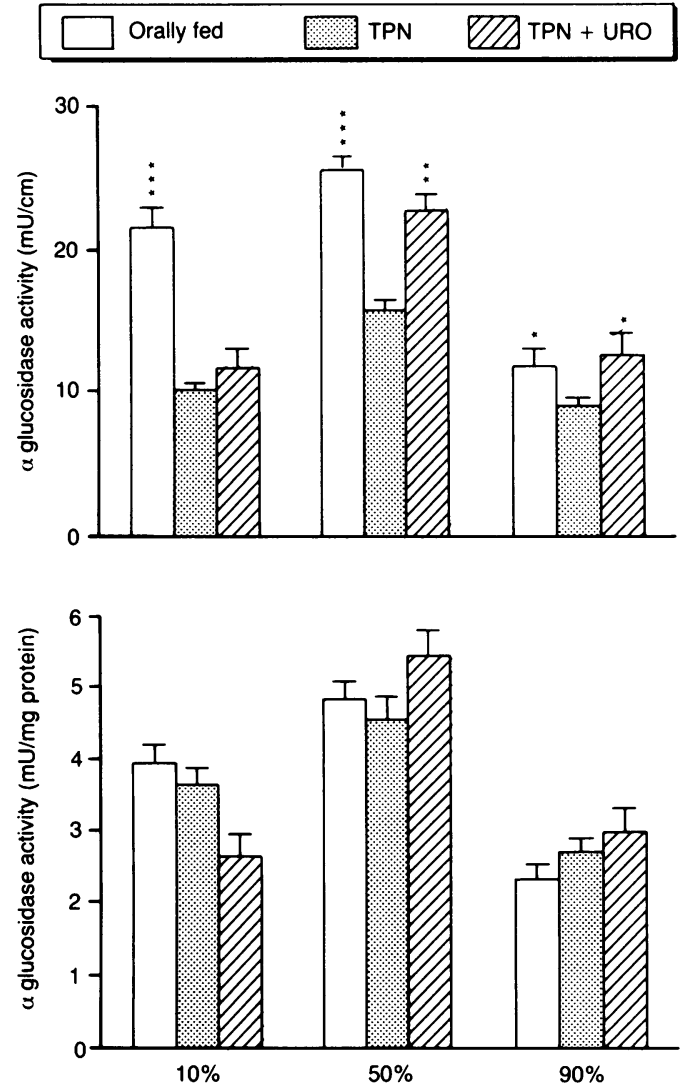

Figure 5: Effects of oral feeding, intravenous nutrition $(T P N)$, and TPN + urogastrone-epidermal growth factor (URO) on intestinal $\alpha$ glucosidase activity $(\mathrm{mU} / \mathrm{cm})$ and specific activity ( $\mathrm{mU} / \mathrm{mg}$ protein). The sites in the intestine were defined by their percentage length from the proximal end. Significantly greater than the TPN group: ${ }^{\star} p<0.05$, $\star \star p<0.01, \star \star \star p<0.001$.

1 Carpenter G. Epidermal growth factor. In: Baserga R, ed. Tissue growth factors Berlin: Springer-Verlag 1981:89-123. Tissue growth factors. Berlin: Springer-Verlag, 1981: 89-123.
Calvert R, Beaulieu JF, Menard D. Epidermal growth factor Calvert R, Beaulieu JF, Menard D. Epidermal growth factor
(EGF) accelerates the maturation of foetal mouse mucosa in utero. Experientia 1982; 38: 1096.

3 Weaver LT, Walker WA. Epidermal growth factor and the developing human gut. Gastroenterology 1988; 94: 845-7.

4 Goodlad RA, Wright NA. Peptides and epithelial growth regulation. Experientia 1987; 43: 780-4.

5 Oka Y, Ghrisan FK, Grene HL, Orth DN. Effects of mouse epidermal growth factor/urogastrone on functional maturation of rat intestine. Endocrinology 1983; 112: 940-4.

6 Beaulieu JF, Menard D, Calvert R. Influence of epidermal growth factor on the maturation of the foetal mouse duogrowth factor on the maturation of the foetal mouse duo476-81.
7 O'Loughlin EV, Chung M, Hollenberg M, Hayden J, Zahavi I, Gall DG. Effect of epidermal growth factor on ontogeny of , Gall DG. Effect of epidermal growt factor on ontogeny

8 Goodlad RA, Wilson TG, Lenton W, Wright NA, Gregory H McCullagh KG. Urogastrone-epidermal growth factor is trophic to the intestinal epithelium of parenterally fed rats. Experientia 1985; 41: 1161-3.

9 Goodlad RA, Wilson TG, Lenton W, Wright NA, Gregory $H$ McCullagh KG. Intravenous but not intragastric urogastrone-EGF is trophic to the intestinal epithelium of parenterally fed rats. Gut $1987 ; 28: 573-82$.

10 Walker-Smith JA, Phillips AD, Walford N, Gregory $H$ Fitzgerald JD, McCullagh K, et al. Intravenous epidermal growth factor/urogastrone increases small intestinal cell proliferation in congenital microvillous atrophy. Lancet proliferation in 1985 ; ii: $1239-40$.

11 Feldman EJ, Aures D, Grossman MI. Epidermal growth factor stimulates ornithine decarboxylase activity in the digestive tract of the mouse. Proc Soc Exp Biol Med 1978; 159: 400-2.

12 Smith J, Cook E, Fotheringham I, Phelby S, Derbyshire R, Eaton MAW, et al. Chemical synthesis and cloning of a gene for human $\beta$-urogastrone. Nucleic Acids Res 1982 10: 446782 .

13 Peters TJ. Analytical subcellular fractionation of jejunal biopsy specimens: methodology and characterisation of the organelles in normal tissue. Clin Sci Mol Med 1976; 51 (suppl): 557-74.

14 Smith GD, Ding JL, Peters TJ. A sensitive fluorimetric assay for $\gamma$-glutamyltransferase. Anal Biochem 1979; 100: 136-9.

15 Bradford MM. A rapid and sensitive method for the quantification of microgram quantities of protein utilizing the cation of microgram quantities of protein utilizing the
principle of protein-dye binding. Anal Biochem 1976; 72: principle

16 Tannock IF. A comparison of the relative efficiencies of various metaphase arrest agents. Exp Cell Res 1967; 47: 34556.

17 Wright NA, Carter J, Irwin M. The measurement of villus cell population size in the mouse small intestine in normal and abnormal states: a comparison of absolute measurements with morphometric estimators in sectioned immersion fixed material Cell Tissue Kinet 1989; 22: 425-50.

18 Pothier P, Menard D. Presence and characteristics of epidermal growth factor receptors in human foetal small intestine and colon. FEBS Lett 1988; 228: 113-7.

19 Goodlad RA, Madgwick AJA, Moffatt MR, Levin S, Allen JL, Wright NA. Prostaglandins and the gastric epithelium: effects of misoprostol on gastric epithelial cell proliferation in the dog. Gut 1989; 30: 316-21.

20 Patel EK, Bruce SE, Bjarnason I, Peters TJ. Rat gastrointestinal transglutaminase: demonstration of enzyme activity and cell and tissue distribution. Cell Biochem Funct 1985; 3: 199 203.

21 Goodlad RA, Plumb JA, Wright NA. Epithelial cell proliferation and intestinal absorptive function during starvation and tion and intestinal absorptive function during st

22 Menard D, Arsenault P, Pothier P. Biologic effects of epidermal growth factor in human fetal jejunum. Gastroenterology

23 Thornburg W, Rao RK, Matrisian LM, Magun BE, Koldovsky O. Effect of maturation on gastrointestinal absorption of epidermal growth factor in rats. Am $\mathcal{F}$ Physiol 1987; 253: G68-71.

24 Schwartz MZ, Storozuk RB. Influence of epidermal growth factor on intestinal function in the rat: comparison of systemic infusion versus luminal perfusion. $A m \mathcal{F}$ Surg 1988; 155: 18-22.

25 Raia KB Simpson RJ, Gregory H, Peters TJ. Effect of orally administered epidermal growth factor on intestinal iron absorption and mucosal permeability. Cell Biochem Funct 1989; 7: 157-63. 